TITLE:

\title{
Mycotoxin Detection in Urine Samples from Patients with Chronic Kidney Disease of Uncertain Etiology in Sri Lanka
}

\section{AUTHOR(S):}

Desalegn, Biruck; Nanayakkara, Shanika; Harada, Kouji H.; Hitomi, Toshiaki; Chandrajith, Rohana; Karunaratne, Upul; Abeysekera, Tilak; Koizumi, Akio

\section{CITATION:}

Desalegn, Biruck ...[et al]. Mycotoxin Detection in Urine Samples from Patients with Chronic Kidney Disease of Uncertain Etiology in Sri Lanka. Bulletin of Environmental Contamination and Toxicology 2011, 87(1): 6-10

\section{ISSUE DATE:}

2011-07

URL:

http://hdl.handle.net/2433/143570

\section{RIGHT:}

The final publication is available at www.springerlink.com; この論文は 出版社版でありません。引用の際には出版社版をご確認ご利用くださ $\omega_{\circ}$; This is not the published version. Please cite only the published version. 
1 Mycotoxin Detection in Urine Samples from Patients with Chronic Kidney

2 Disease of Uncertain Etiology in Sri Lanka

3

4 Biruck Desalegn ${ }^{1}$, Shanika Nanayakkara ${ }^{1}$, Kouji H. Harada ${ }^{1}$, Toshiaki Hitomi ${ }^{1}$,

5 Rohana Chandrajith ${ }^{2}$, Upul Karunaratne ${ }^{3}$, Tilak Abeysekera ${ }^{3}$, and Akio Koizumi ${ }^{1}$

6 for the Chronic Kidney Disease of Uncertain Etiology Consortium ${ }^{4}$

7

$8{ }^{1}$ Department of Health and Environmental Sciences, Kyoto University Graduate

9 School of Medicine, Yoshida, Kyoto 606-8501, Japan

$10{ }^{2}$ Department of Geology, Faculty of Science, University of Peradeniya, Sri Lanka

$11{ }^{3}$ Nephrology Unit, Teaching Hospital, Kandy, Sri Lanka

$12{ }^{4} \mathrm{~A}$ full list of members is provided in the supplementary note.

14 Correspondence to: Akio Koizumi M.D., Ph.D.

15 Department of Health and Environmental Sciences, Graduate School of Medicine,

16 Kyoto University, Yoshida Konoe, Sakyo, Kyoto 606-8501, Japan

17 Tel: +81-75-753-4456; Fax: +81-75-753-4458

18 E-mail: Akio.Koizumi@z06.mbox.media.kyoto-u.ac.jp 


\section{Abstract}

22 This was a screening study that aimed to determine the presence of nephrotoxic

23 mycotoxins in urine samples from patients with chronic kidney disease of

24 uncertain etiology (CKDue) in the North Central Province of Sri Lanka. The

25 percentage detection of aflatoxins (AFLs), ochratoxins (OTs) and fumonisins in

2631 patients were $61.29 \%, 93.5 \%$ and $19.4 \%$, respectively. Geometric means of

27 urinary AFLs and OTs were $30.93 \mathrm{ng} / \mathrm{g} \mathrm{Cr}$ (creatinine) and $34.62 \mathrm{ng} / \mathrm{g} \mathrm{Cr}$ in

28 CKDue stage 1-2 patients and $84.12 \mathrm{ng} / \mathrm{g} \mathrm{Cr}$ and $63.52 \mathrm{ng} / \mathrm{g} \mathrm{Cr}$ in unaffected

29 relatives of patients. In CKDue stage 3-5 patients, geometric means of urinary

30 AFLs and OTs were 10.40 and $17.08 \mathrm{ng} / \mathrm{g} \mathrm{Cr}$, respectively. Non-affected relatives

31 of patients ( $n=6)$ had comparable levels of these mycotoxins, but healthy Japanese

32 individuals $(n=4)$ had lower levels than in Sri Lanka. The higher detection rate of

33 urinary OTs in Sri Lankans indicates that exposure is common in the region.

34 Keywords chronic kidney disease of uncertain etiology, Sri Lanka, urine sample,

35 aflatoxin, ochratoxin, fumonisin 
37 High prevalence of chronic kidney disease of uncertain etiology (CKDue) in the

38 North Central Province of Sri Lanka has been reported. The disease

39 predominantly affects male farming communities. Several hypotheses have been

40 made to explain the causal associations between the high prevalence of the disease

41 in the region and existing environmental factors (Chandrajith et al. 2010;

42 Illeperuma et al. 2009).

Mycotoxins, such as aflatoxins (AFLs) (Glahn et al. 1994), ochratoxins

44 (OTs) (Sauvant et al. 2005) and fumonisins (FBs) (Badria et al. 1996) are dietary

45 contaminants that are known to possess nephrotoxicity. Detection of OT

46 associated with the incidence of endemic nephropathy in some regions has been

47 reported (Castegnaro et al. 2005; Domijan et al. 2009). A recent study by

48 Wanigasuriya et al. (2008) has reported that the concentration of OT A in selected

49 food items in the study region was low. Food analysis, in some instances, might

50 not be sufficient to establish a relationship with occurrence of diseases because

51 heterogeneity of toxin distribution over time, and even within a particular food

52 product, casts doubt on the feasibility of sampling plans (Parson et al. 2007). In an

53 attempt to overcome this problem and to validate the actual exposure, we screened

54 urinary excretion levels of AFL, OTs and FBs in patients and their relatives living

55 in a CKD endemic community.

\section{$57 \quad$ Materials and Methods}

58 Ethical approval for this study was obtained from the Ethical Committee of Kyoto

59 University, Japan and the Ethical Review Committees of the Faculty of Medicine, 
60 University of Peradeniya, Sri Lanka. The urine samples were originally collected

61 at Medawachchiya and Girandrukotte, Sri Lanka in August 2009 (106 patients and

6287 unaffected relatives of CKDue patients) and stored at $-30^{\circ} \mathrm{C}$ in the Kyoto

63 University Human Specimen Bank (Koizumi et al. 2009). A total of 41 urine

64 samples, 31 from stage 1-5 CKDue patients, six from unaffected relatives, and

65 four from healthy Japanese individuals as controls, were randomly selected from

66 each stratum. Definition of CKD and further classification of the stages were

67 made according to the Kidney Disease Outcomes Quality Initiative (KDOQI)

68 guidelines. Patients with a history and current treatment of diabetes mellitus,

69 severe hypertension, urological disease of known etiology, glomerulonephritis, or

70 snake bite were excluded. Creatinine concentration in urine sample was measured

71 by enzyme assay using creatinine amidohydrolase (SRL, Tokyo, Japan). Urine samples were thawed and centrifuged at $15,000 \mathrm{rpm}$ for $10 \mathrm{~min}$ to remove any cellular debris, and the supernatant was used for the determination of mycotoxin level. One milliliter of urine was diluted with $3 \mathrm{~mL}$ PBS (pH 7.4). The

75 mixed sample was directly passed through analyte-specific immunoaffinity

76 columns (R-Biopharm AG, Darmstadt, Germany) at a flow rate of 1-2 drops/s.

77 The column was washed with $20 \mathrm{~mL}$ PBS and air was passed through the column

78 for $1 \mathrm{~min}$. The bound mycotoxin was eluted with $3 \mathrm{~mL}$ methanol and the eluate

79 was evaporated to dryness using a nitrogen evaporator. The residue was

80 reconstituted with $100 \mu \mathrm{L} 10 \%$ methanol in water, and analyzed for each

81 mycotoxin with the specific competitive ELISA kits (RIDASCREEN FAST

82 Mycotoxins; R-Biopharm AG) using a microplate spectrophotometer (infinite 
83 M200 Pro; Tecan, Tokyo, Japan) at $450 \mathrm{~nm}$. ELISA kits for AFL, OTs and FBs

84 recognized aflatoxins $\mathrm{B} 1, \mathrm{~B} 2, \mathrm{G} 1, \mathrm{G} 2$ and $\mathrm{M} 1$; ochratoxins $\mathrm{A}, \mathrm{B}$ and $\mathrm{C}$, and

85 fumonisins B1, B2 and B3, respectively. External standards of different

concentrations and all urine samples were run in duplicate.

(13) for OTs and 92\% (15) for FBs. Detection limits were $0.005 \mathrm{ng} / \mathrm{mL}, 0.005$

$\mathrm{ng} / \mathrm{mL}$ and $0.035 \mathrm{ng} / \mathrm{mL}$ for AFLs, OTs and FBs, respectively. For values below the detection limit, half of the limit of detection value was assigned. Mycotoxin concentrations are presented in $\mathrm{ng} / \mathrm{mL}$ and $\mathrm{ng} / \mathrm{g} \mathrm{Cr}$ (creatinine). Statistical significance of differences was tested by using non-parametric methods $\left(\chi^{2}\right.$ test and Wilcoxon two-sample test; $P<0.05)$.

\section{Results and Discussion}

Study subjects comprised 20 men and 21 women (Table 1). The mean (range) age regardless of disease stage (31, stage $1-5)$ was $41.32 \pm 15.55$ (9-65) years, whereas that of unaffected relatives and Japanese controls was 20.67 (6-34) years and $45.25(42-53)$ years, respectively.

Results of urinary AFL, OT and FB levels are shown in Table 2. The percentage detection of AFLs, OTs and FBs in patients was $61.29 \%, 93.5 \%$ and $19.4 \%$, respectively. The detection rate of all mycotoxins in stage 1 disease was

103 the highest. Disease stages were classified as early (stage 1 and 2) and late (stage $1043-5)$ for examination of concentration differences during disease progression. 
respectively $\left(\chi^{2}=9.323 ; P<0.001\right)$. OTs were detected in all of the urine samples from 14 patients with early stage disease, whereas the rate of detection at the late stage was $88.24 \%(n=17)\left(\chi^{2}=23.516, P<0.001\right)$. Both AFLs and OTs were detected in all of the relatives of CKDue patients, but only OTs were detected in the Japanese controls.

The highest AFL concentration in urine samples from CKDue patients was $0.8 \mathrm{ng} / \mathrm{mL}$, whereas $90 \%$ of the samples had a concentration $<0.044 \mathrm{ng} / \mathrm{mL}$ (397.1 $\mathrm{ng} / \mathrm{g} \mathrm{Cr})$. The 90th percentile for OTs was $0.098 \mathrm{ng} / \mathrm{mL}(60.85 \mathrm{ng} / \mathrm{g} \mathrm{Cr})$. The geometric means of urinary AFLs and OTs were $0.033 \mathrm{ng} / \mathrm{mL}(30.93 \mathrm{ng} / \mathrm{g} \mathrm{Cr})$ and $0.037 \mathrm{ng} / \mathrm{mL}(34.62 \mathrm{ng} / \mathrm{g} \mathrm{Cr})$ in the early stage, and $0.008 \mathrm{ng} / \mathrm{mL}(10.40 \mathrm{ng} / \mathrm{g} \mathrm{Cr})$ and $0.012 \mathrm{ng} / \mathrm{mL}(17.08 \mathrm{ng} / \mathrm{g} \mathrm{Cr})$ in the late stage of the disease. Mean concentration difference for urinary OT level was observed between the early and late stages of the disease (Wilcoxon test, $P=0.008$ ). In contrast, comparable concentrations of OTs and AFLs were also observed in the unaffected relatives of CKDue patients $(P>0.05$ compared with all patients). Healthy Japanese individuals, however, had lower levels of OTs $(0.007 \mathrm{ng} / \mathrm{mL}, 8.14 \mathrm{ng} / \mathrm{g} \mathrm{Cr})$ than Sri Lankan individuals had.

The small sample size of the control subjects and their characteristic differences with the patients limit the comparability of the results. However, the high detection frequency and urinary levels of OTs and AFLs among CKDue patients and their relatives demonstrated the potential human exposure in the region. Findings were also discussed in relation to similar studies in other countries (Table 3). The average AFL concentration in urine samples from 
129 CKDue patients was markedly higher, by over an order of magnitude, than the

130 level of $0.391 \mathrm{ng} / \mathrm{g} \mathrm{Cr}$ in the Czech Republic (Malir et al. 2004). An FB exposure study in two Portuguese populations has shown no detectable level in urine samples (Silva et al. 2008) and in Mexico 75\% detection frequency was observed (Gong et al. 2008), whereas some level of FBs was detected at the early stage of 134 the disease in the present study.

Higher detection of OTs was observed compared with the $61 \%$ detection rate among healthy individuals in Hungary and $43 \%$ in the endemic nephropathy area in Croatia (Domijan et al. 2009), whereas the detection was comparable with the $88-97.8 \%$ in the endemic nephropathy region of Bulgaria (Castegnaro et al. 2005). Although the mean OT level in CKDue patients in our study was higher than the $0.007 \mathrm{ng} / \mathrm{mL}$ in Croatia (Domijan et al. 2009) and $0.013 \mathrm{ng} / \mathrm{mL}$ in Hungary (Fazekas et al. 2004), and was comparable to the $0.022 \mathrm{ng} / \mathrm{mL}$ in Portugal (Duarte et al. 2010), the urine concentration levels in half of our CKDue patients were $<0.017 \mathrm{ng} / \mathrm{mL}(n=15)$. The potential sources of exposure to OTs in 144 the region need to be clarified.

Animal studies have demonstrated the possibility of higher concentrations of OT A in kidney tissues and low levels in the urine (Zepnik et al. 2003).

147 Likewise, an increase in OT A intake in humans in the region of endemic nephropathy did not result in an immediate increase in its elimination (Castegnaro 149 et al. 2005). OT A is characterized by high plasma protein binding potential, 150 therefore, its removal efficiency might be low (Petzinger et al. 2000; Ringot et al. 151 2006), and it is possible that OT A accumulates in renal tissue. It is worth noting 
152 that the cumulative effect of long-term consumption of products that contain low

153 levels of mycotoxins could contribute to a gradual deterioration of organ function.

154 This study is believed to be the first to determine the presence of AFLs,

155 OTs and FBs in urine samples from CKDue patients and their relatives living in

156 communities with CKDue. The higher detection rate of OTs in Sri Lanka has led

157 to a working hypothesis that this mycotoxin could be common in the region,

158 which corroborates the need for further exposure assessment, associated with

159 disease occurrence.

160

\section{Acknowledgments}

162 This work was supported by special coordination funds for promoting science and 163 technology sponsored by the Japan Science and Technology Agency. The funder 164 had no role in the study design, data collection and analysis, decision to publish, 165 or preparation of the manuscript. The authors have declared that they have no 166 competing interests.

168 References

169 Badria FA, Li S, Shier WT (1996) Fumonisins as Potential Causes of Kidney

170 Disease. Toxin Reviews 15:273-292

171 Castegnaro M, Canadas D, Vrabcheva T, Petkova-Bocharova T, Chernozemsky

172 IN, Pfohl-Leszkowicz A (2006) Balkan endemic nephropathy: Role of

173 ochratoxins A through biomarkers. Mol Nutr Food Res 50:519 - 529

174 Chandrajith R, Nanayakkara S, Itai K, Aturaliya TNC, Dissanayake CB,

175 Abeysekera T, Harada K, Watanabe T, Koizumi A (2010) Chronic kidney

176 diseases of uncertain etiology (CKDue) in Sri Lanka: geographic distribution and 
177 environmental implications. Environ Geochem Health. Doi:10.1007/s10653-010-

178 9339-1

179 Domijan A-M, Peraica M, MArkov K, Fuchs R (2009) Urine Ochratoxin A and

180 sphinganine/sphingosine ratio in residents of the endemic nephropathy area in

181 Croatia. Arh Hig Rada Toksikol 60:387-393

182 Duarte S, Bento J, Pena A, Lino CM, Delerue-Matos C, Oliva-Teles T, Morais S, 183 Correia M, Oliveira MB, Alves MR, Pereira JA (2010) Monitoring of ochratoxin

184 A exposure of the Portuguese population through a nationwide urine survey -

185 Winter 2007. Science of the Total Environment 408:1195-1198

186 Fazekas B, Tar A, KOVÁCS M (2005) Ochratoxin A content of urine samples of

187 healthy humans in Hungary. Acta Veterinaria Hungarica 53: 35-44

188 Glahn RP, Van Campen D, Dousa TP (1994) Aflatoxin B1 reduces Na(+)-P(i) co-

189 transport in proximal renal epithelium: studies in opossum kidney (OK) cells.

190 Toxicology 92:91-100

191 Gong Y, Hounsa A, Egal S, Turner PC, Sutcliffe AE, Hall AJ, Cardwell K, Wild

192 CP (2004) Postweaning Exposure to Aflatoxin Results in Impaired Child Growth:

193 A Longitudinal Study in Benin, West Africa. Environ Health Perspect 112:1334-

1941338

195 Illeperuma OA, Dharmagunawardhane HA, Herarh KPRP (2009) Dissolution of

196 aluminium from substandard utensils under high fluoride stress: A possible risk

197 factors for chronic renal failures in the North-Central Provice. Journal of the

198 National Science Foundation of Sri Lanka 37:219-222

199 Koizumi A, Harada K, Inoue K, Hitomi T, Yang H-R, Moon C-S, Wang P, Hung

200 N, Watanabe T, Shimbo S, Ikeda M (2009) Past, present, and future of

201 environmental specimen banks. Environ Health Prev Med 14:307-18

202 Malir F, Ostry V, Cernia M, Kacerovsky J, Roubal T, Skarkova J, Brndiar M,

203 Fixa P (2004) Monitoring the important mycotoxin biomarkers (ochratoxin A,

204 aflatoxin M1) in the Czech population. Cas Lek Cesk 143:691-6

205 Parsons D, Casado MR, Magan N, Dyer C, Weightman R (2007) Development of

206 representative sampling plans for mycotoxins in foods using distribution modeling.

207 Final report to the UK Food Standards Agency Project CO3055: Wolverhampton,

208 ADAS UK Ltd.

209 Petzinger E and Weidenbach A (2002) Mycotoxins in the food chain: the role of

210 ochratoxins. Livestock Production Science 76:245-250 
211 Ringot D, Changoa A, Schneider YJ, Larondelle Y (2006) Toxicokinetics and

212 toxicodynamics of ochratoxin A, an update. Chemico-Biological Interactions

$213 \quad 159: 18-46$

214 Sauvant C, Holzinger H, Mildenberger S, Gekle M (2005) Exposure to

215 nephrotoxic ochratoxin A enhances collagen secretion in human renal proximal

216 tubular cells. Mol Nutr Food Res 49:31-7

217 Silva LJ, Pena A, Lino CM, Fernandez MF, Manes J (2010)Fumonisin

218 determination in urine by LC-MS-MS. Anal Bioanal Chem 396:809-16

219 Wanigasuriya KP, Peiris H, Ileperuma N, Peiris-John RJ, Wickremasinghe R

220 (2008) Could ochratoxin A in food commodities be the cause of chronic kidney

221 disease in Sri Lanka? Trans R Soc Trop Med Hyg 102:726-728

222 Zepnik H, Volkel W, Dekant W (2003) Toxicokinetics of the mycotoxin

223 ochratoxin A in F 344 rats after oral administration. Toxicology and Applied

224 Pharmacology 192:36-44

225

226 
228 Table 1. Baseline characteristics of CKDue patients in Sri Lanka, 2009 Disease stages Sex Age (yr) male/female mean (range)

\begin{tabular}{ccc} 
& $\begin{array}{c}\text { male/female } \\
\text { (Total) }\end{array}$ & mean (range) \\
\hline Stage 1 (slight) & $3 / 4$ & $24.14(9-40)$ \\
Stage 2 (mild) & $6 / 1$ & $48(39-59)$ \\
Stage 1-2 (early stage) & $9 / 5(14)$ & $36.07 \pm 15.19$
\end{tabular}

\begin{tabular}{ccc}
\hline Stage 3 (moderate) & $3 / 3$ & $41(11-60)$ \\
Stage 4 (severe) & $3 / 3$ & $47.5(35-58)$ \\
Stage 5 (end stage) & $3 / 2$ & $49.00(30-65)$ \\
Stage 3-5 (late stage) & $9 / 8(17)$ & $45.65 \pm 14.90$ \\
\hline $\begin{array}{c}\text { Total (CKDue } \\
\text { patients) }\end{array}$ & $18 / 13$ & $41.32 \pm 15.55(9-65)$ \\
\hline $\begin{array}{c}\text { Relatives of CKDue } \\
\text { patients }\end{array}$ & $2 / 4$ & $20.67(6-34)$ \\
\hline Japanese controls & $0 / 4$ & $45.25(42-53)$ \\
\hline
\end{tabular}


231 Table 2. Urine concentration of AFL, OT and FB in CKDue patients in Sri Lanka, 2322009.

\begin{tabular}{|c|c|c|c|c|c|c|c|}
\hline \multirow[t]{2}{*}{ Subjects } & & \multicolumn{2}{|c|}{ AFL } & \multicolumn{2}{|c|}{ OT } & \multicolumn{2}{|c|}{$\mathrm{FB}$} \\
\hline & & $\mathrm{ng} / \mathrm{mL}$ & $\mathrm{ng} / \mathrm{g} \mathrm{Cr}$ & $\mathrm{ng} / \mathrm{mL}$ & $\mathrm{ng} / \mathrm{g} \mathrm{Cr}$ & $\mathrm{ng} / \mathrm{mL}$ & $\mu \mathrm{g} / \mathrm{g} \mathrm{Cr}$ \\
\hline \multirow[t]{3}{*}{$\begin{array}{l}\text { Stage } 1(n= \\
7)\end{array}$} & $\begin{array}{l}\text { Range } \\
(n>M D L)\end{array}$ & ND-0.800(6) & ND-734.00 & $\begin{array}{c}0.013-0.360 \\
\text { (7) }\end{array}$ & $\begin{array}{c}17.63- \\
93.90\end{array}$ & $\begin{array}{c}\text { ND- } \\
0.042 \\
(4)\end{array}$ & $\begin{array}{l}\text { ND- } \\
0.14\end{array}$ \\
\hline & Mean & 0.359 & 230.21 & 0.044 & 39.67 & $<\mathrm{MDL}$ & $<\mathrm{MDL}$ \\
\hline & GM & 0.092 & 87.41 & 0.035 & 33.33 & $<\mathrm{MDL}$ & $<\mathrm{MDL}$ \\
\hline \multirow[t]{3}{*}{$\begin{array}{l}\text { Stage } 2(n= \\
7)\end{array}$} & $\begin{array}{l}\text { Range } \\
(n>M D L)\end{array}$ & ND-0.037 (5) & ND-53.05 & $\begin{array}{c}0.006-0.058 \\
\text { (6) }\end{array}$ & $\begin{array}{c}11.87- \\
74.81\end{array}$ & $\begin{array}{c}\text { ND- } \\
0.036 \\
(1)\end{array}$ & $\begin{array}{l}\text { ND- } \\
0.07\end{array}$ \\
\hline & Mean & 0.018 & 19.58 & 0.085 & 65.07 & - & - \\
\hline & GM & 0.012 & 10.95 & 0.039 & 35.95 & - & - \\
\hline Stage 1-2 & GM & 0.033 & 30.93 & 0.037 & $34.62 *$ & - & - \\
\hline \multirow[t]{3}{*}{$\begin{array}{l}\text { Stage } 3(n= \\
6)\end{array}$} & $\begin{array}{l}\text { Range } \\
(n>M D L)\end{array}$ & ND-0.039 (4) & ND-44.74 & ND-0.028 (5) & $8.57-41.25$ & $\begin{array}{c}\text { ND- } \\
0.130 \\
(1)\end{array}$ & $\begin{array}{l}\text { ND- } \\
0.19\end{array}$ \\
\hline & Mean & 0.023 & 25.57 & 0.022 & 21.76 & - & - \\
\hline & GM & 0.022 & 18.75 & 0.016 & 19.36 & - & - \\
\hline \multirow[t]{3}{*}{$\begin{array}{l}\text { Stage } 4(n= \\
6)\end{array}$} & $\begin{array}{l}\text { Range } \\
(n>M D L)\end{array}$ & ND-0.800 (4) & ND-991.57 & ND-0.019 (4) & ND-34.27 & - & - \\
\hline & Mean & 0.140 & 174.82 & 0.016 & 18.75 & ND & ND \\
\hline & GM & 0.009 & 12.71 & 0.012 & 17.07 & - & - \\
\hline \multirow[t]{3}{*}{$\begin{array}{l}\text { Stage } 5(n= \\
5)\end{array}$} & $\begin{array}{l}\text { Range } \\
(n>M D L)\end{array}$ & ND & ND & $0.010(4)$ & ND-27.06 & ND & ND \\
\hline & Mean & - & - & 0.044 & 16.56 & - & - \\
\hline & GM & - & - & 0.080 & 14.72 & - & - \\
\hline Stage 3-5 & GM & 0.008 & 10.40 & 0.012 & $17.08^{*}$ & - & - \\
\hline Stage $1-5$ & GM & 0.012 & 17.01 & 0.020 & 23.50 & - & - \\
\hline \multirow[t]{3}{*}{$\begin{array}{l}\text { Relatives } \\
\text { controls }(n= \\
6)\end{array}$} & $\begin{array}{l}\text { Range } \\
(n>M D L)\end{array}$ & $0.020-0.800(6)$ & $5.9-1000.00$ & $\begin{array}{c}0.032-0.223 \\
\text { (6) }\end{array}$ & $\begin{array}{l}28.63- \\
278.00\end{array}$ & $\begin{array}{c}\text { ND- } \\
0.093 \\
(1)\end{array}$ & $\begin{array}{l}\text { ND- } \\
0.14\end{array}$ \\
\hline & Mean & 0.298 & 249.09 & 0.104 & 88.95 & - & - \\
\hline & GM & 0.112 & 84.12 & 0.085 & 63.52 & - & - \\
\hline \multirow{3}{*}{$\begin{array}{l}\text { Japanese } \\
\text { controls }(n= \\
\text { 4) }\end{array}$} & $\begin{array}{l}\text { Range } \\
(n>M D L)\end{array}$ & ND & ND & $\begin{array}{c}0.005-0.012 \\
\text { (4) }\end{array}$ & $4.4-19.40$ & ND & ND \\
\hline & Mean & - & - & 0.007 & 9.69 & - & - \\
\hline & GM & - & - & 0.007 & 8.14 & - & - \\
\hline
\end{tabular}

233 ND: not detected; MDL: method detection limit; GM: geometric mean

$234 *$ Wilcoxon test for mean OT concentration difference between early and late stages $(P=0.008)$

235

236

237

238 
239 Table 3. Urine mycotoxin level in other countries

\begin{tabular}{|c|c|c|c|c|c|}
\hline $\begin{array}{l}\text { Mycotoxin } \\
\text { Type }\end{array}$ & $\begin{array}{l}\text { Detection } \\
\text { rate }\end{array}$ & Mean (range) & Study subjects & Country & Reference \\
\hline \multirow[t]{2}{*}{ AFL } & $61.29 \%$ & $\begin{array}{l}17.0(\mathrm{ND}-991.6) \\
\mathrm{ng} / \mathrm{gCr}\end{array}$ & CKDue patients & Sri Lanka & Present study \\
\hline & $58 \%$ & $\begin{array}{l}391.0 \text { (19.0- } \\
19,219.0) \mathrm{pg} / \mathrm{g} \mathrm{Cr}\end{array}$ & General population & $\begin{array}{l}\text { Czech } \\
\text { Republic }\end{array}$ & $\begin{array}{l}\text { (Malir et al. } \\
\text { 2004) }\end{array}$ \\
\hline \multirow[t]{8}{*}{ OT A } & $100 \%$ & $\begin{array}{l}37.1(12.4-360.0) \\
\mathrm{pg} / \mathrm{mL}\end{array}$ & $\begin{array}{l}\text { CKDue patients } \\
\text { (early stage) }\end{array}$ & Sri Lanka & Present study \\
\hline & $88.24 \%$ & $\begin{array}{l}12.0(\mathrm{ND}-58.2) \\
\mathrm{pg} / \mathrm{mL}\end{array}$ & $\begin{array}{l}\text { CKDue patients (late } \\
\text { stage) }\end{array}$ & Sri Lanka & Present study \\
\hline & $100 \%(n=6)$ & $\begin{array}{l}85.0(32.0-223.0) \\
\mathrm{pg} / \mathrm{mL}\end{array}$ & $\begin{array}{l}\text { Relatives of CKDue } \\
\text { patients }\end{array}$ & Sri Lanka & Present study \\
\hline & $61 \%$ & $\begin{array}{l}13.0(6.0-65.0) \\
\mathrm{pg} / \mathrm{mL}\end{array}$ & Healthy individuals & Hungary & $\begin{array}{l}\text { (Fazekas et al. } \\
\text { 2004) }\end{array}$ \\
\hline & $43 \%$ & $7.0(5.0-15.0) \mathrm{pg} / \mathrm{mL}$ & Endemic nephropathy & Croatia & $\begin{array}{l}\text { (Domijan et al. } \\
\text { 2009) }\end{array}$ \\
\hline & $92.20 \%$ & $\begin{array}{l}22.0(\mathrm{ND}-69.0) \\
\mathrm{pg} / \mathrm{mL}\end{array}$ & General population & Portugal & $\begin{array}{l}\text { (Duarte et al. } \\
\text { 2010) }\end{array}$ \\
\hline & $88 \%$ & $\begin{array}{l}50.8(1.0-330.0) \\
\mathrm{pg} / \mathrm{mL}\end{array}$ & Endemic nephropathy & Bulgaria & $\begin{array}{l}\text { (Castegnaro et } \\
\text { al. 2005) }\end{array}$ \\
\hline & $97.6 \%$ & $\begin{array}{l}191.7(1.0-191.0) \\
\mathrm{pg} / \mathrm{mL}\end{array}$ & Endemic nephropathy & Bulgaria & $\begin{array}{l}\text { (Castegnaro et } \\
\text { al. 2005) }\end{array}$ \\
\hline \multirow[t]{3}{*}{ FB } & $19.4 \%$ & $(\mathrm{ND}-130.0 \mathrm{pg} / \mathrm{mL})$ & CKDue patients & Sri Lanka & Present study \\
\hline & \multicolumn{2}{|c|}{$0 \%(\mathrm{LOD}=5 \mathrm{ng} / \mathrm{mL})$} & General population & Portugal & $\begin{array}{l}\text { (Silva et al. } \\
\text { 2008) }\end{array}$ \\
\hline & $75 \%$ & $\begin{array}{l}70.1 \text { (ND-9312.0) } \\
\mathrm{pg} / \mathrm{mL}\end{array}$ & General population & Mexico & $\begin{array}{l}\text { (Gong et al. } \\
\text { 2008) }\end{array}$ \\
\hline
\end{tabular}

240 